\title{
Wpływ jakości zysku na zależność pomiędzy zyskiem a stopą zwrotu z akcji na przykładzie GPW w Warszawie
}

\begin{abstract}
Rafat Cieślik*
$W$ artykule podjęto próbę oceny tego czy $i w$ jakim zakresie jakość zysku determinuje przydatność wyniku finansowego dla prognozowania ceny akcji (stopy zwrotu) $w$ warunkach polskiego rynku kapitatowego. Dla oceny jakości zysku wykorzystano wskaźniki oparte na czterech jego atrybutach, tj. trwatości, zdolności predykcyjnej, stopniu wygtadzania zysku oraz stabilności. Wyniki badania oparte na szerokiej próbie obejmujacej wszystkie niefinansowe spótki notowane na GPW w Warszawie w latach 2009-2016 pozwolity potwierdzić pozytywny wplyw, jaki wywiera jakości zysku na badana zależność. Należy jednak podkreślić, że sita tego wptywu jest zmienna w czasie i zależy od przynależności sektorowej badanej spótki.
\end{abstract}

Słowa kluczowe: jakość zysku, stopa zwrotu, trwałość zysku, zdolność predykcyjna, wygładzanie zysku.

Nadesłany: 21.11.2016 | Zaakceptowany do druku: 22.12.2016

\section{Effect of Earnings Quality on the Returns-Earnings Relationship: Evidence from the Warsaw Stock Exchange}

The paper examines whether and how earnings quality affects the returns-earnings relationship taking into consideration four earnings attributes including persistence, predictability, smoothness and stability. For a large sample of non-financial firms listed on the Warsaw Stock Exchange over the period 2009-2016, the study showed that earnings quality has a positive influence on the tested relationship. Moreover, the nature (parameters) of the returns/earnings relation exhibits considerable instability over time and across sectors.

Keywords: earnings quality, stock market return, persistence, predictability, smoothness.

Submitted: 21.11.2016 | Accepted: 22.12.2016

JEL: G11, G17

Rafal Cieślik - dr, Wydział Zarządzania, Uniwersytet Warszawski.

Adres do korespondencji: Wydział Zarządzania, Uniwersytet Warszawski, ul. Szturmowa 1/3, 02-678 Warszawa; e-mail: rcieslik@wz.uw.edu.pl. 


\section{Wprowadzenie}

W trakcie ostatnich kilku dekad obserwuje się rosnące zainteresowanie zarówno teoretyków, jak i praktyków z dziedziny finansów i rachunkowości poszukiwaniem istotnych zależności pomiędzy poszczególnymi kategoriami ekonomicznymi ujawnianymi w sprawozdaniu finansowym a kategoriami identyfikującymi efektywność inwestycyjną, tj. ceną akcji, stopą zwrotu bądź ponadprzeciętną stopą zwrotu. Zależność ta określana jest w literaturze terminem value relevance of accounting numbers. Zaś zainteresowanie badawcze w tym obszarze koncentruje się szczególnie na ocenie, czy dostępne publicznie dane księgowe oraz które i kiedy determinują proces decyzyjny inwestorów giełdowych.

Analizy empiryczne w tym zakresie opierają się na założeniu, że jeżeli informacja wpływa na proces decyzyjny, to inwestorzy dostosowują swoje decyzje do jej zachowania, a rynek reaguje na jej upublicznienie poprzez zmianę ceny akcji. Zatem, aby informacja była użyteczna dla procesu wyceny rynkowej, musimy obserwować zależność pomiędzy reakcją rynku a jej ujawnieniem. Jeżeli taka reakcja występuje oraz jest pozytywna i silna, wówczas możemy mówić o wysokiej użyteczności decyzyjnej takiej informacji. Jeżeli natomiast reakcja jest słaba lub negatywna, wówczas użyteczność decyzyjna informacji jest wątpliwa.

Opisywana w literaturze przedmiotu i szeroko przebadana zależność pomiędzy wynikiem finansowym a wyceną rynkowa spółki (stopą zwrotu z akcji) zasadniczo opiera się na trzech założeniach. Po pierwsze zakłada się, że zysk lub szerzej dane finansowe zawarte w sprawozdaniu dostarczają akcjonariuszom informacji na temat bieżącej i przyszłej zyskowności. Po drugie przyjmuje się, że informacje o bieżącej i przyszłej zyskowności dostarczają akcjonariuszom informacji na temat obecnej i potencjalnej dywidendzie oraz są użyteczne dla przewidywania przyszłych przepływów pieniężnych. Po trzecie przyjmuje się, że cena akcji odzwierciedla wartość bieżącą (zdyskontowaną) przyszłych dywidend, bądź, szerzej, wolnych przepływów pieniężnych należnych akcjonariuszom. Niestety badania empiryczne prowadzone w tym zakresie na świecie nie potwierdzają w pełni występowania powyższych relacji w praktyce. Ball i Brown (1968), na pod- stawie prostego modelu, wykazali istnienie pozytywnej zależności pomiędzy stopą zwrotu z akcji a zyskiem, ale już w bardziej współczesnym opracowaniu Lev (1989) wyprowadził wniosek, że zysk jedynie w 10-15\% wyjaśnia zmiany cen akcji. Co więcej parametry opisujące naturę relacji zysk-stopa zwrotu z akcji wykazują niestabilność w czasie, co z kolei pokazuje, że 'przydatność zysku dla inwestorów jest bardzo ograniczona. Inni badacze próbowali określić przyczyny takiego stanu rzeczy wskazując m.in. na:

- niedopasowanie modelu - np. Easton i Harris (1991), Shroff (2002), Abdelqader, Al-Debi'e i Gharaibeh (2008),

- irracjonalność podejmowania przez inwestorów decyzji,

- jakość danych sprawozdawczych ,jakość zysku" - np. Penman i Zhang (2002), Chan $\mathrm{i}$ in. (2004), Richardson $\mathrm{i}$ in. (2005), Dechow i Dichev (2002), Houge i Loughran (2000).

O ile dwa pierwsze obszary są stosunkowo dobrze opisane i przebadane, także w warunkach polskich (np. Gajdka i Pietraszewski, 2015; Zurawik, 2012; Majewski i Doszyń, 2013), o tyle problematyka wpływu jakości zysku na użyteczność informacji sprawozdawczych dla procesu prognozowania stopy zwrotu $\mathrm{z}$ akcji jest w opracowaniach krajowych zagadnieniem nowym.

Problematyka jakości zysku łączy się ze zjawiskiem „kreatywnej rachunkowości", czyli wykorzystywania dopuszczonych w systemach rachunkowości praw wyboru i alternatywnych rozwiązań w zakresie wyceny aktywów i pasywów oraz przychodów i kosztów do intencjonalnego kształtowania danych finansowych prezentowanych w sprawozdaniu finansowym. Te alternatywności, co do zasady, mają zapewnić wysoką jakość informacji finansowej, jednak w praktyce są wykorzystywane przez zarządzających do „kreowania” wyniku finansowego, tak aby wpłynać na odbiorców tych informacji i zachęcić ich do podejmowania określonych decyzji. Przykładem stosowania takich praktyk może być szereg skandali z początku XXI wieku. Przypadki Enronu, Tyco International czy Xeroxa to tylko najbardziej spektakularne przykłady manipulacji księgowych, które odcisnęły swój negatywny ślad na rynkach kapitałowych. W tym kontekście celem autora jest 
wykazanie, czy i w jakim zakresie jakość zysku determinuje przydatność wyniku finansowego dla prognozowania ceny akcji (stopy zwrotu) w warunkach polskiego rynku kapitałowego. Należy tu podkreślić, że zamierzeniem autora w ramach niniejszego opracowania nie jest budowanie nowego modelu prognostycznego, a jedynie wykazanie, czy taka teoretycznie uzasadniona zależność w ujęciu praktycznym i w warunkach polskich w ogóle istnieje. Badanie to można zatem potraktować jako wstęp do szerszego opracowania, w którym autor, wykorzystując wyniki analizy empirycznej, będzie starał się opracować model prognozowania cen akcji z wykorzystaniem parametru jakości zysku ${ }^{1}$.

\section{Zysk jako zmienna objaśniająca zmianę stopy zwrotu z akcji}

Problematyka użyteczności decyzyjnej zysku dla rynku kapitałowego była przedmiotem rozważań wielu badań teoretycznych i empirycznych. Między innymi V. Bernard (1995) przeprowadził analizę porównawczą, w ramach której z jednej strony badał wpływ na cenę akcji informacji w zakresie wartości księgowej oraz wyniku finansowego, z drugiej oceniał relację pomiędzy ceną akcji a wielkością wypłacanej dywidendy. Wykorzystywał w tym celu model oparty na analizie regresji ceny akcji wzgledem tych czynników. Wyniki badań wskazywały, że w pierwszym przypadku współczynnik determinacji liniowej osiągał wyraźnie wyższy poziom (przeciętna wartość współczynnika $\mathrm{R}^{2}$ wyniosła $68 \%$ ). W modelu opartym na wartości dywidendy przeciętna wartość współczynnika $\mathrm{R}^{2}$ wyniosła jedynie $29 \%$. Wyniki te potwierdziły zatem występowanie pozytywnej zależności pomiędzy analizowanymi wielkościami, których wartość jest prezentowana w sprawozdaniu finansowym, a wartością firmy. W ramach analiz empirycznych dokonywano także oceny porównawczej różnej wartości decyzyjnej informacji pochodzacych z bilansu i rachunku zysków i strat. Między innymi Collins i in. (1997) wskazali, że w trakcie ostatnich czterdziestu lat użyteczność decyzyjna zysku spadła, zaś użyteczność decyzyjna wartości księgowej wzrosła. Wyniki te zostały potwierdzone także w badaniach Bartha $\mathrm{i}$ in (1998). W tym ostatnim przypadku wnioski odnosity się do przedsiębiorstw znajdujących się w kłopotach finansowych. Można to interpretować intuicyjnie w ten sposób, że w sytuacji, gdy spółka wykazuje niską dochodowość bądź jej brak, inwestorzy opierają swoje decyzje na wycenie majątkowej.

Powyższy przegląd literatury wskazuje, że dane sprawozdawcze, w tym także zysk księgowy, stanowią istotny czynnik procesu podejmowania decyzji inwestycyjnej, chociaż ich wpływ na ten proces w ostatnich latach nieznacznie się osłabił. Należy tu jednak podkreślić, że prawdziwość tych wniosków jest w dużej mierze zależna od przyjętej w badaniu metodologii, tj. potwierdza się dla jednej metodologii badawczej, dla innej wyniki nie są już tak jednoznaczne (Cho, 2005).

Ogólny model definiujący zależność pomiędzy informacjami pochodzącymi $\mathrm{z}$ rachunkowości a wartością rynkową akcji może przybierać następującą postać:

$$
V=f(A, v)
$$

gdzie „, $V$ może oznaczać dowolną miarę odzwierciedlająca wartość rynkową akcji Może to być np. bieżąca cena akcji bądź też stopa zwrotu uzyskana za dany okres. Parametr , $A$ " z kolei może stanowić wektor zmiennych (danych) księgowych, np. zysk na jedną akcję, a parametrem „v" może być wektor dowolnych informacji innych niż te tworzone przez system rachunkowości (Luberrink, 2000).

Opisując relacje pomiędzy wielkościami ekonomicznymi prezentowanymi w sprawozdawczości finansowej a ceną rynkową akcji lub stopą zwrotu z akcji, często wykorzystuje się podstawowy model wyceny, w którym cena akcji (wartość przedsiębiorstwa) odzwierciedla przyszłe zdyskontowane przepływy pieniężne. Ponieważ jednak informacje o przyszłych przepływach pieniężnych nie są prezentowane w raportach finansowych spółek giełdowych, powszechne zainteresowanie inwestorów budzi kategoria zysku (Kothari i Zimmerman, 1995). Wynika to z faktu, że zysk bieżaccy, co zreszta stwierdzaja wprost Międzynarodowe Standardy Rachunkowości, zawiera informacje w zakresie oczekiwanych przyszłych przepływów pieniężnych (Watts i Zimmerman, 1986; Kormendi i Lipe, 1987; Ohlson, 1991). Stąd w sposób naturalny wynik finansowy stał się podstawową kategorią księgową, wykorzystaną w modelu regresji jako zmienna objaśniająca zmianę ceny akcji (stopy zwrotu). 
W literaturze przedmiotu najczęściej zastosowanie mają trzy modele opisujące zależność pomiędzy zyskiem $X_{t}$ a ceną akacji $P_{t}$ (Kothari i Zimmerman, 1995): model cena - zysk

$$
P_{t}=\alpha+\beta X_{t}+\varepsilon_{t}
$$

model indeksu ceny

$$
P_{t} / P_{t-1}=\alpha+\beta X_{t} / P_{t-1}+\varepsilon_{t}
$$

model stopy zwrotu

$$
\Delta P_{t}=\alpha+\beta \Delta X_{t} / P_{t-1}+\varepsilon_{t}
$$

W pierwszym przypadku zmienną objaśniającą zmianę ceny akcji jest zysk księgowy, w drugim zysk jest zmienną objaśniającą dla stopy zwrotu z akcji za dany okres. $\mathrm{Z}$ kolei w trzecim modelu czynnikiem wyjaśniającym zmianę stopy zwrotu z akcji w danym okresie jest obserwowana w tym okresie zmiana poziomu zysku.

\section{Jakość zysku - istota i pomiar}

W nauce ekonomii istnieją dwie wariantowe koncepcje dotyczące formułowania wyniku finansowego. Pierwsza $\mathrm{z}$ nich wiąże się z zachowaniem kapitału (tzw. podejście księgowe - transakcyjne). Koncepcja ta opiera się na teorii strumieni i pomija równocześnie większość zmian dotyczących rynkowej wartości komponentów tworzących bogactwo firmy. Druga koncepcja, nazywana podejściem ekonomicznym, koncentruje się na maksymalizacji wartości ekonomicznej i traktuje wynik finansowy jako maksymalną wartość, o jaką wzrosło bogactwo firmy na koniec okresu w porównaniu z jego początkiem. Przy pomiarze wartości uwzględnia się szereg czynników w tym także zmiany wartości rynkowej komponentów tworzących owe bogactwo Tradycyjna rachunkowość przyjęła pierwszą z wymienionych koncepcji oraz wypracowała dla niej swoje własne metody interpretacji i pomiaru wyniku finansowego. Szeroka alternatywność w zakresie interpretacji i pomiaru wielkości czynników kształtujących wynik finansowy oraz jego różne formy pośrednie (wynik na sprzedaży, wynik na działalności operacyjnej, wynik netto) pozwala postawić zasadnicze pytanie o użyteczność tej kategorii ekonomicznej dla procesu podejmowania decyzji
- szczególnie zaś w zakresie konkretnych cech jakościowych determinujących tę użyteczność.

Termin ,jakość zysku” nie jest jeszcze powszechnie używanym, szczególnie w polskiej literaturze, określeniem wskazującym na pewne ważne i pożądane cechy tej kategorii. Nie jest jednakże pojęciem nowym. Zarówno w opracowaniach naukowych, jak i w literaturze anglosaskiej kontekst jakości zysku z reguły utożsamiany jest z pojęciem earnings quality, chociaż, jak dotąd, nie została sformułowana jednoznaczna i ogólnie akceptowalna jego definicja. Problem związany z jednoznaczną egzegezą tego terminu wynika zarówno z celu, jak i normatywnych aspektów funkcjonowania systemu rachunkowości w różnych państwach i różnych przedsiębiorstwach. Istotnym czynnikiem stanowiącym trudność definiowania tego pojęcia jest także szeroki krąg użytkowników informacji finansowych, a co za tym idzie formułowanie przez nich różnych oczekiwań w zakresie cech jakościowych, jakimi powinien charakteryzować się zysk.

Jednym $\mathrm{z}$ celów rachunkowości jako źródła informacji o przedsiębiorstwie jest zapewnienie zgodności pomiędzy występującymi w przedsiębiorstwie zdarzeniami ekonomicznymi a danymi finansowymi tworzonymi i udostępnianymi publicznie w ramach sprawozdawczości finansowej. $\mathrm{Z}$ tej perspektywy zysk księgowy charakteryzuje się wysoką jakością wtedy, kiedy wiernie odzwierciedla wszystkie zdarzenia kształtujące jego wartość. Natomiast miarą oceny jakości zysku w tym przypadku może być różnica pomiędzy poziomem wyniku finansowego zaprezentowanego w raporcie finansowym a jego poziomem rzeczywistym, który ma pokrycie $\mathrm{w}$ zdarzeniach ekonomicznych.

Rachunkowość finansowa, zgodnie z zasadą memoriałową, ewidencjonuje wszystkie zdarzenia gospodarcze, zarówno te o charakterze niepieniężnym, których skutki finansowe pojawią się w przyszłości, jak i pieniężnym, obejmujace wszelkie płatności otrzymane lub dokonane w przeszłości. Ta perspektywa implikuje z kolei fakt, że zysk prezentowany $\mathrm{w}$ raporcie finansowym jest wynikiem nie tylko niegotówkowego (czysto memoriałowego), lecz także gotówkowego poziomu komponentów kształtujących jego wartość. Jednocześnie poziom niegotówkowy tych komponentów ustalany jest $\mathrm{w}$ oparciu o wycenę bilan- 
sową. Procedura wyceny bilansowej jest prowadzona zgodnie $\mathrm{z}$ uregulowaniami prawnymi, w ramach których dopuszczone są pewne alternatywne sposoby postępowania, tzw. prawa wyboru oraz obszary swobody. Te z kolei mogą być intencjonalnie wykorzystywane przez menedżerów do wpływania na poziom prezentowanego zysku. Można więc uznać, że zysk posiada wysoką jakość wtedy, gdy w trakcie jego tworzenia nie dokonywano zmian metod księgowych określonych w polityce rachunkowości, tak aby intencjonalnie kształtować poziom prezentowanego w raporcie wyniku finansowego. Można także uznać, że jakość zysku jest tym wyższa, w im większym stopniu zysk księgowy pokrywa się z zyskiem gotówkowym. Mniejszy udział zysku czysto memoriałowego pozostawia bowiem mniejsze pole do manipulacji.

Jakość zysku to także kryterium będące synonimem wartości poznawczej i decyzyjnej informacji pochodzących ze sprawozdawczości finansowej dla ich użytkowników. $\mathrm{Z}$ tej perspektywy jakość zysku może być identyfikowana poprzez zdolność bieżącego zysku do utrzymania swego poziomu w przyszłości. Wyższa trwałość zysku zwiększa jego zdolność predykcyjną, a to z kolei zwiększa jego użyteczność decyzyjną (Francis i in., 2004).

Wszystko to pokazuje, iż jednoznaczne zdefiniowanie pojęcia ,jakość zysku” jest bardzo trudne, a w literaturze przedmiotu termin ten najczęściej jest utożsamiany z (Dichev i in., 2013):

- trwałością zysku (ang. persistence), np. Penman i Zhang (2002), Dechow i Schrand (2004), Melumad i Nissim (2009);

- wygładzeniem zysku (ang. smoothness), np. Francis i in. (2004), Dechow i Schrand (2004);

- zdolnością predykcyjną (ang. predictability), np. Schipper i Vincent (2003);

- brakiem wpływu na wartość prezentowanego zysku zdarzeń jednorazowych i nadzwyczajnych, np. Dechow i Schrand (2004), McVay (2006);

- stosowaniem w sposób konserwatywny zasad rachunkowości, np. Watts (2003a, 2003b);

- odzwierciedleniem zysku w przeszłych, bieżących i przyszłych przepływach pieniężnych, np. Sloan (1996), Dechow i Dichev (2002);

- niewielkimi zmianami poziomu różnic memoriałowych, gdy nie są one rezultatem zmian fundamentalnych, np. DeAngelo (1986), Jones (1991), Dechow i in. (1995),

Kothari i in. (2005).

Używając różnych cech określających jakość zysku, naukowcy i analitycy rozwinęli kilka definicji oraz modeli mierzących to kryterium, przy czym każdy model może być użyty do bardzo wąskich celów wynikających $\mathrm{z}$ przedstawionych $\mathrm{w}$ definicji założeń. Kiedy założenia badania i założenia modelu pokrywają się tylko częściowo, żaden z nich nie dostarczy wszechstronnego pomiaru jakości zysku.

W praktyce jakość zysku może być mierzona w oparciu o szereg czynników. Czynniki te w literaturze przedmiotu sa określane jako ,atrybuty zysku” i są najczęściej klasyfikowane w ramach dwóch grup, tj. atrybutów księgowych (ang. accounting-based attributes) i atrybutów rynkowych (ang. market-based attributes).

W niniejszym badaniu jakość zysku jest definiowana jako ogół cech i właściwości zysku księgowego, które decydują o jego użyteczności dla procesu podejmowania decyzji ekonomicznych. Skupiono się tu na trzech atrybutach księgowych, do których literatura przedmiotu zalicza (Francis i in., 2004):

- trwałość zysku (ang. persistence),

- użyteczność prognostyczna (ang. predictability),

- wygładzenie (ang. smoothness).

Przegląd literaturowy w zakresie oceny trwałości i predykcyjności zysku wskazuje na dwa zasadnicze podejścia powszechnie wykorzystywane w tym zakresie. W ramach pierwszego szacowanie trwałości parametrów opiera sie na analizie szeregów czasowych historycznych danych dotyczących wyniku finansowego (Kormendi i Lipe, 1987). W drugim - dla oszacowania trwałości zysku wykorzystuje się fundamentalne dla oceny kondycji ekonomicznej firmy dane księgowe (Lev i Thiagarajan, 1993).

$\mathrm{W}$ ramach pierwszego podejścia ocena trwałości zysku jest realizowana poprzez porównanie wyniku finansowego bieżacego okresu z wynikiem przeszłym. Jeżeli różnica porównania jest dodatnia i jednocześnie zależność ta jest obserwowana w dłuższym horyzoncie czasu, wówczas można przewidywać, że taka tendencja utrzyma się w przyszłości. Stąd dla określenia trwałości i predykcyjności zysku w niniejszym opracowaniu zastosowano podejście zaproponowane przez Francis i in. (1987): 


$$
X_{j, t}=\phi_{0, j}+\phi_{1, j} X_{j, t-1}+v_{j, t}
$$

gdzie: $\mathrm{X}_{j, t}$ to zysk netto $\mathrm{z}$ wyłączeniem zdarzeń jednorazowych i nadzwyczajnych dla przedsiębiorstwa $j$ oraz roku $t$ ważony sumą aktywów, jakie jednostka posiadała na początku roku t.

Trwałość zysku jest określana na podstawie współczynnika regresji liniowej $\phi_{1, j}$. Wartość $\phi_{1, j}$ bliska jedności jest interpretowana jako wysoka trwałość zysku. Jeżeli natomiast wartość ta jest zbliżona do zera, wówczas wynik finansowy charakteryzuje się wysoką zmiennością (Francis i in., 2004 s. 980).

Wartość zysku w tym podejściu jest ważona ogólną sumą aktywów. Poziom zaangażowanego w majątek kapitału odzwierciedla w tym przypadku wielkość przedsiębiorstwa. Jest to niezbędne dla zachowania porównywalności wyników pomiędzy różnymi przedsiębiorstwami. Małe firmy w branżach o wysokiej koncentracji mogą mieć większy problem w stosunku do dużych firm z utrzymywaniem stabilnej stopy zwrotu, co jest wynikiem słabej ich siły konkurencyjnej.

Predykcyjność zysku to cecha związana z użytecznością wyniku finansowego dla przewidywania jego wartości w przyszłości i jest specyficzna dla indywidualnego procesu prognozowania realizowanego przez poszczególnych użytkowników informacji finansowych. Wysoka trwałość zysku zwiększa jego użyteczność prognostyczną. Stąd w literaturze przedmiotu predykcyjność jest szacowana poprzez analizę poziomu dopasowania funkcji regresji określonej w formule 5 do danych empirycznych. W niniejszym opracowaniu przyjęto założenie, że zdolność prognostyczna jest tym wyższa, w im większym stopniu wartość bieżącego zysku jest wyjaśniona poprzez zysk z roku poprzedniego. Wartość ta jest odzwierciedlona poprzez współczynnik determinacji liniowej $\mathrm{R}^{2}$.

Wygładzanie zysków (ang. smoothness) może być definiowane jako proces, w ramach którego dochodzi do intencjonalnego wpływu na zmienność poziomu zysków, w wyniku czego tworzy się uznawany za normalny dla danej firmy i w danym okresie poziom zysku (Beidleman, 1973). Praktyki wygładzania zysku opierają się na przekonaniu, że uczestnicy rynku w swych decyzjach zasugerują się trwałym w czasie strumieniem zysku wykazywanym przez przedsiębiorstwo. Szereg metod szacowania ryzyka inwestycyjnego opiera się bowiem na ocenie zdolności prognostycznej zysku oraz analizie zmienności zysku w czasie. Jeżeli zatem wyeliminujemy wysoki wzrost lub spadek zysku w bieżącym okresie w stosunku do okresu ubiegłego, wpłyniemy na ocenę ryzyka inwestycyjnego dokonywaną przez rynek w stosunku do danej firmy.

Dla oceny wygładzania zysków Leuz $\mathrm{i}$ in. (2003) wykorzystali przepływy pieniężne z działalności operacyjnej (CFO) jako odpowiednika (zysku niewygładzonego) i dokonali pomiaru wygładzenia jako wskaźnika prezentującego relację zmienności zysków do zmienności przepływów pieniężnych. W innym opracowaniu Bowen $i$ in. (2003) dokonali pomiaru wygładzenia zysku jako relacji odchylenia standardowego przepływów pieniężnych z działalności operacyjnej do odchylenia standardowego zysku. Z kolei Francis i in. (2004) dokonali pomiaru wygładzenia zysku jako relacji odchylenia standardowego zysku netto z wyłączeniem zdarzeń jednorazowych i nadzwyczajnych, tak jak proponowali Bowen i in. (2003), ale dokonali standaryzacji (zachowali porównywalność) danych poprzez podzielenie parametrów przez aktywa $\mathrm{z}$ początku roku. W niniejszym opracowaniu wykorzystano podejście zaproponowane przez Francis i in. (2004) według następującego wzoru:

$$
\sigma\left(N I B E_{j, t}\right) / \sigma\left(C F O_{j, t}\right)
$$

gdzie: NIBE to zysk netto $z$ wyłączeniem zdarzeń jednorazowych i nadzwyczajnych dla przedsiębiorstwa j oraz roku t ważony sumą aktywów jakie jednostka posiadała na początku roku t.

Wysoka wartość tego wskaźnika jest interpretowana jako niskie wygładzenie zysków.

W opracowaniu wykorzystano także dodatkowy miernik, stabilności zysku (ang. stability of earnings), który zaproponowali w swoim opracowaniu Alaa'A i al.-Debi'e (2015). Stabilność zysku jest tu określona jako relacja różnicy między zyskiem netto prezentowanym przez przedsiębiorstwo w roku $t$ i wartością średnią zysku netto z 10 lat poprzedzających rok badany a odchyleniem standardowym zysku netto 
w okresie 10 lat poprzedzających rok badany.

$$
Z_{j t}=\left(X_{j t}-\mu\right) / \sigma
$$

\section{Zależność pomiędzy wynikiem finansowym a stopą zwrotu $\mathrm{z}$ akcji: analiza empiryczna}

\subsection{Metodologia badawcza}

Ocena wpływu jakości zysku na użyteczność informacji sprawozdawczych dla procesu prognozowania stopy zwrotu z akcji obejmuje dwa etapy.

W etapie pierwszym dla każdej spółki objętej badaniem i poszczególnych lat dokonano wyliczenia czterech mierników jakości zysku, tj. trwałości zysku (EQ1), zdolności prognostycznej (EQ2), wygładzenia zysku (EQ3) i stabilności zysku (EQ4), wykorzystując metodologię opisaną w części 3. Wartość każdego z czterech wskaźników została oszacowana na podstawie szeregów czasowych obejmujących dane z 10 lat.

Pomimo iż w badaniu zastosowano metodologie oceny jakości zysku, która została szeroko opisana $\mathrm{w}$ literaturze przedmiotu i przetestowana $w$ ramach innych badań należy wskazać na związane $\mathrm{z}$ nią pewne problemy interpretacyjne. Dotyczy to dwóch atrybutów jakościowych zysku, tj. wygładzania zysku oraz stabilności zysku, których wyniki mogą być interpretowane w różny sposób. $\mathrm{Z}$ jednej strony wygładzony zysk może oznaczać, iż został on intencjonalnie wykreowany przez zarządzających a to oznacza niska jakość zysku. Z drugiej strony może oznaczać, iż zysk charakteryzuje się wysoką przydatnościa decyzyjną. Dlatego w opracowaniu przyjęto założenie, że wysoka jakość zysku jest utożsamiana $\mathrm{z}$ wysokim poziomem wszystkich wskaźników EQ.

W kolejnym kroku, na podstawie każdego z czterech wskaźników z osobna, dokonano podziału całej próby badawczej na dwie grupy jakościowe:

- najlepsze $40 \%$ - obejmujacca przypadki charakteryzujące się najwyższym poziomem wskaźnika EQ,

- najgorsze $40 \%$ - obejmujacca przypadki charakteryzujące się najniższym poziomem wskaźnika EQ.

Pozostałe 20\% obserwacji zostało pominięte $\mathrm{w}$ badaniu. Przypadki te osiągają umiarkowane i zbliżone poziomem wyniki, zatem ich zaliczenie do różnych grup jakościowych mogłoby zniekształcić wyniki estymacji.

W kolejnym etapie w ramach całej próby, a następnie w ramach dwóch grup jakościowych (najlepsze $40 \%$ i najgorsze $40 \%$ ) dokonano analizy regresji zależności pomiędzy zyskiem z roku poprzedniego a ceną akcji z wykorzystaniem następującej formuły:

$$
P_{t} / P_{t-1}=\beta_{0}+\beta_{1} X_{t-1} / P_{t-1}+\varepsilon_{t}
$$

gdzie:

$P_{t} \quad$ - kurs akcji w roku t,

$P_{t-1}-$ kurs akcji w roku $t-1$,

$\beta_{0}, \beta_{1}$ - parametry estymacji,

$X_{t-1}$ - zysk netto na jedną akcję ( EPS Earnings per share) w roku $t-1$,

$\varepsilon_{t} \quad$-wartość resztowa.

Indeks ceny $\left(P_{t} /\right)$ odzwierciedla tu relację kursu akcji z końca i początku okresu, przy czym okres ten rozpoczyna się w maju roku $t-1$ i kończy w kwietniu roku $t$.

Podstawowe znaczenie dla identyfikacji siły objaśniającej zmianę ceny rynkowej akcji przez zysk mają współczynnik determinacji $\mathrm{R}^{2}$ oraz parametr estymacji $\beta_{1}$ reprezentujaccy tzw. earnings response coefficient (ERC). Wysoka i pozytywna wartość tego współczynnika wskazuje, że zysk księgowy ma silny wplyw na proces wyceny akcji. Porównywanie poziomu tego współczynnika w różnych okresach może być podstawą oceny zmiany użyteczności decyzyjnej zysku w czasie (Lev i in., 1999). Należy jednak pamiętać, że wskaźnik ten, jak wynika $\mathrm{z}$ szeregu przeprowadzonych w tym zakresie badań, posiada wyższą wartość interpretacyjną w przypadku firm zyskownych niż w przypadku firm generujących straty (Hayn, 1995).

\subsection{Opis próby badawczej}

Badaniem objęto dane zawarte w sprawozdaniach finansowych spółek notowanych na Giełdzie Papierów Wartościowych w Warszawie w latach 2009-2016 spełniających kryteria badania. Z badania wyłączono spółki z sektora finansowego. Przyjęta metodologia oceny jakości zysku oparta na analizie szeregów czasowych obejmujących 10 letnie przedziały spowodowała, że zakres czasowy danych wykorzystanych w badaniu obejmował lata 1999-2016. Dla 
uniknięcia wyłączenia z próby zbyt wielu przedsiębiorstw w badaniu nie wprowadzono ograniczenia dostępności danych z całego okresu 18 lat dla wszystkich firm objętych badaniem. Konsekwencją przyjętego rozwiązania są różnice w liczebności próby badawczej w ujęciu rocznym. Całkowita liczba obserwacji po wyłączeniu tych, dla których brakowało danych, liczyła 905 przypadków. Jednakże po wyłączeniu wielkości skrajnych (1. i 99. percentyl) ostatecznie próba liczyła 803 przypadków. Szczegółowe statystyki opisowe dla zmiennych wykorzystanych dla oceny jakości zysku zaprezentowano w tabeli 1 .

Zgodnie $\mathrm{z}$ danymi zawartymi w tabeli 1 średnia i mediana dla indeksu ceny i ważonego wskaźnika zysku na jedną akację (EPS) osiąga wartość dodatnia $i$ to na poziomie zarówno wielkości średniej, jak i mediany. Warto podkreślić, że wskaźnik EPS odchyla się od średniej $(0,054)$ o $0,776 \mathrm{w}$ obie strony, a wskaźnik indeksu ceny odchyla się od średniej $(0,189)$ o 0,844 . Oznacza to, że próba obejmująca 803 przypadków jest silnie zróż- nicowana nawet po wyłączeniu wielkości skrajnych.

Przechodzac do analizy wyników w zakresie czterech atrybutów jakościowych, możemy zaobserwować, że wskaźnik trwałości zysku osiąga wartość średnią (mediane) na poziomie $0,257(0,255)$. Dla porównania wartość średnia wskaźnika EQ1 w badaniu przeprowadzonym przez Perotti i Wagenhofer (2014) dla 1370 firm i zakresu czasowego obejmujacego dane z lat 1978-2008 wyniosła 0,36. W obszarze zdolności predykcyjnej wskaźnik EQ2 osiągnął z kolei wartość średnią (medianę) na poziomie $0,17(0,105)$ przy odchyleniu standardowym 0,179 . Dla porównania Perotti i Wagenhofer (2014), podobnie jak w poprzednim przypadku, wykazali wyższa wartość wskaźnika wynoszącą 0,239. Wyniki te oznaczają, że trwałość i predykcyjność zysku polskich spółek giełdowych w tym porównaniu jest niższa.

W obszarze „zysku wygładzonego" wskaźnik EQ3 osiąga wartość średnia (medianę) na poziomie $1,3(0,98)$. Dla porównania Leuz i in. (2003) przeprowa-

Tabela 1. Statystyki opisowe dla próby badawczej po wyłączeniu wielkości skrajnych.

\begin{tabular}{|c|c|c|c|c|c|c|c|c|}
\hline Zmienna & 乙 & 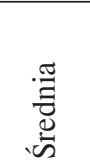 & 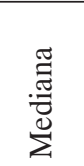 &  & 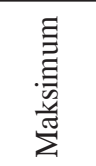 & ن. & જे & $\begin{array}{l}\frac{7}{0} \\
\frac{0}{0} \\
\frac{0}{0} \\
0\end{array}$ \\
\hline $\begin{array}{l}\text { Stabilność } \\
\text { zysku } \\
\text { EQ4 }\end{array}$ & 803 & 0,291 & 0,337 & $-8,667$ & 6,420 & $-4,912$ & 4,546 & 1,614 \\
\hline $\begin{array}{l}\text { Wygładzenie } \\
\text { zysku } \\
\text { EQ3 }\end{array}$ & 803 & 1,305 & 0,983 & 0,125 & 8,722 & 0,173 & 7,098 & 1,221 \\
\hline $\begin{array}{l}\text { Zdolność } \\
\text { prognostyczna } \\
\text { EQ2 }\end{array}$ & 803 & 0,174 & 0,105 & 0,000 & 0,745 & 0,001 & 0,656 & 0,179 \\
\hline $\begin{array}{l}\text { Trwatość } \\
\text { zysku } \\
\text { EQ1 }\end{array}$ & 803 & 0,257 & 0,255 & $-0,521$ & 1,171 & $-0,460$ & 0,910 & 0,320 \\
\hline $\begin{array}{l}\text { Indeks ceny } \\
P_{t} / P_{t-1}\end{array}$ & 803 & 1,189 & 1,026 & 0,216 & 10,188 & 0,34 & 5,143 & 0,844 \\
\hline $\begin{array}{l}\text { Ważony } \\
\text { wskaźnik EPS } \\
X_{t-1} / P_{t-1}\end{array}$ & 803 & 0,054 & 0,003 & $-5,284$ & 8,176 & $-1,827$ & 3,112 & 0,776 \\
\hline
\end{tabular}

Źródło: opracowanie własne na podstawie danych spółek. 
dzając podobne badanie dla warunków amerykańskich i okresu obejmującego lata 1990-1999 uzyskali wartość wskaźnika na poziomie 0,765 , a Perotti i Wagenhofer (2014) w ramach bardziej współczesnych badań osiągnęli wartość 0,709 . W zakresie stabilności zysku miernik EQ4 osiągną wartość średnią (medianę) na poziomie $0,29(0,33)$, co jest wartością znacznie wyższą niż w podobnym badaniu przeprowadzonym przez Alaa' i Al-Debi'e (2015), gdzie osiągnął on średnią wartość 0,049 .

Wyniki te wskazują, iż w warunkach polskich wyniki finansowe spółek giełdowych charakteryzują się niższą trwałością i zdolnością predykcyjna oraz mniejszym wygładzeniem i stabilnością.

\subsection{Wyniki analizy empirycznej}

Wyniki badania zostały zawarte w tabelach 2-6. Zaprezentowano w nich rezultaty analizy regresji zależności pomiędzy stopą zwrotu a zyskiem. Zarówno proces analizy regresji, jak i statystyki opisowe realizowane są za pomocą programu statystycznego STATISTICA w wersji 12 . Ze względu na ograniczenie objętości niniejszego opracowania w tabeli 2 zawarto pełne wyniki estymacji zarówno dla całej próby badawczej, jak i dla dwóch grup jakościowych wyodrębnionych na podstawie każdego z czterech wskaźników jakościowych. W tabelach 3-5 zawarto pełne wyniki estymacji dla próby badawczej wyodrębnionej dla poszczególnych sektorów i jako porównanie dla próby (najlepsze $40 \%$ ) w każdym sektorze. W tabeli 6 zawarto jedynie podstawowe wyniki estymacji (współczynnik determinacji $\mathrm{R}^{2}$, parametr b dla zmiennej niezależnej oraz odpowiadający statystyce $\mathrm{t}$, wykorzystywanej do oceny istotności współczynnika regresji, poziom prawdopodobieństwa p) dla danych „surowych” i poszczególnych lat objętych badaniem, i jako porównanie, wyniki dla próby obejmujaccej spółki charakteryzujacce się wysoką jakością zysku (najlepsze 40\%).

Analizę regresji w pierwszej kolejności przeprowadzono $\mathrm{w}$ ramach całej próby badawczej a następnie w ramach dwóch grup jakościowych wyodrębnionych w oparciu o każdy z czterech wskaźników EQ. Następnie procedurę tę powtórzono w ramach prób badawczych wyodrębnionych w oparciu o przynależność sektorową oraz dla poszczególnych lat objętych badaniem.
Ocena danych panelowych przeprowadzona dla całej próby badawczej (tabela 2) pokazuje, że wskaźnik zysk na jedną akcję (EPS) ważony ceną akcji charakteryzuje sie minimalna wartościa prognostyczną dla stopy zwrotu z akcji. Parametr ERC osiągnął wartość 0,025 przy $\mathrm{R}^{2}$ na poziomie 0,005 . Oznacza to, że poziom zysku wyjaśnia jedynie $0,5 \%$ zmienności ceny akcji. Przeciętna różnica pomiędzy rzeczywistymi wartościami zmiennej zależnej i wartościami przewidywanymi przez model wyniosła 0,85 , co stanowi aż $72 \%$ średniej dla zmiennej zależnej. Niska wartość statystyki $\mathrm{F}(0,42)$ i odpowiadający jej poziom prawdopodobieństwa $\mathrm{p}(\mathrm{p}<0,52)$ wskazują na słabą statystycznie istotność badanej zależności (modelu liniowego). Wartość statystyki t, wykorzystywana do oceny istotności współczynnika regresji $\beta_{1}$, oraz odpowiadający jej poziom prawdopodobieństwa p nie pozwalają założyć, że parametr ten istotnie różni się od zera.

Uwzględnienie oceny jakościowej zysku przy wykorzystaniu miernika Q4 „stabilność" zwiększa przydatność zysku jako czynnika objaśniającego przyszłą stopę zwrotu $\mathrm{z}$ akcji, a parametr ten jest istotny statystycznie, czyli istotnie różni się od zera. Współczynnik ERC zwiększył sie do 0,277 , a współczynnik determinacji $\mathrm{R}^{2}$ wzrósł do poziomu 0,0718 . W odniesieniu do pozostałych wskaźników jakości zysku również zauważalna jest poprawa parametrów bedacych wynikiem estymacji jednak ich wartość jest znacznie niższa. W grupie spółek o niskiej jakości zysku parametr ERC przy wskaźniku EQ1 wyniósł $(-0,28)$, przy EQ2 $(-0,03)$, przy EQ3 $(0,02)$, a przy EQ4 $(-0,10)$. Oznacza to, że w przypadku spółek, których zysk cechuje się niską jakością, przydatność tej kategorii ekonomicznej dla prognozowania stopy zwrotu z akcji jest bardzo niska bądź też wpływ ten jest negatywny. Wzrost zysku powoduje spadek ceny akcji i odwrotnie.

W ujęciu sektorowym (tabele 3-5) również obserwujemy wzrost przydatność zysku jako czynnika objaśniającego stopę zwrotu $\mathrm{z}$ akcji po naniesieniu na dane surowe parametru określającego ,jakość zysku”. W sektorze przemysłowym parametry estymacji dla danych surowych wyniosły: $\mathrm{ERC}=0,30$ przy $\mathrm{R}^{2}$ na poziomie 0,012 , dla sektora handlowego: ERC 0,57 przy $\mathrm{R}^{2}=0,17$ a dla sektora budowlanego: $\mathrm{ERC}=(-0,11)$ przy $\mathrm{R}^{2}=0,002$. Widać zatem wyraźnie, iż 
Tabela 2. Analiza zależności pomiędzy wynikiem finansowym a stopą zwrotu z akcji dla całej próby i porównawczo dla 40\% przypadków o najwyższym i najniższym poziomie wskaźnika jakości zysku

\begin{tabular}{|c|c|c|c|c|c|c|}
\hline \multirow[b]{2}{*}{$\mathrm{N}=803$} & \multicolumn{6}{|c|}{$\begin{array}{l}\text { Podsumowanie regresji zmiennej zależnej: indeks ceny }\left(\mathrm{P}_{\mathrm{t}} / \mathrm{P}_{\mathrm{t}-1}\right) \\
\mathrm{R}=, 02290793 \mathrm{R}^{\wedge} 2=, 00052477 \text { Popraw. } \mathrm{R} 2=----- \\
\mathrm{F}(1,801)=, 42056 \mathrm{p}<, 51684 \text { Błąd std. estymacji: }, 84458\end{array}$} \\
\hline & $\mathrm{b}^{*}$ & Bł. std. & $\mathrm{b}$ & B1. std. & $\mathrm{t}(801)$ & $\mathrm{p}$ \\
\hline W. wolny & & & 0,187 & 0,029878 & 6,269 & 0,000 \\
\hline $\operatorname{Zmn}\left(\mathrm{X}_{\mathrm{t}-1} / \mathrm{P}_{\mathrm{t}-1)}\right)$ & 0,0229 & 0,0353 & 0,025 & 0,038428 & 0,649 & 0,517 \\
\hline \multicolumn{7}{|c|}{$\begin{array}{c}\text { Wskaźnik jakości zysku EQ1 - trwałość zysku } \\
\text { (najlepsze 40\%) }\end{array}$} \\
\hline \multirow[t]{2}{*}{$\begin{array}{l}\mathrm{N}=401 \\
\text { (najlepsze } 40 \% \text { ) }\end{array}$} & \multicolumn{6}{|c|}{$\begin{array}{l}\text { Podsumowanie regresji zmiennej zależnej: indeks ceny }\left(\mathrm{P}_{\mathrm{t}} / \mathrm{P}_{\mathrm{t}-1}\right) \\
\mathrm{R}=, 11225033 \mathrm{R} \wedge 2=, 01260014 \text { Popraw. } R 2=, 01012545 \\
\mathrm{~F}(1,399)=5,0916 \mathrm{p}<, 02458 \text { Błąd std. estymacji: }, 69875\end{array}$} \\
\hline & $b^{*}$ & Bł. std. & $\mathrm{b}$ & B1. std. & $\mathrm{t}(399)$ & $\mathrm{p}$ \\
\hline W. wolny & & & 0,133 & 0,035 & 3,803 & 0,000 \\
\hline $\operatorname{Zmn}\left(\mathrm{X}_{\mathrm{t}-1} / \mathrm{P}_{\mathrm{t}-1)}\right)$ & 0,112 & 0,050 & 0,124 & 0,055 & 2,256 & 0,025 \\
\hline \multicolumn{7}{|c|}{ (najgorsze 40\%) } \\
\hline \multirow[t]{2}{*}{$\mathrm{N}=402$} & \multicolumn{6}{|c|}{$\begin{array}{l}\text { Podsumowanie regresji zmiennej zależnej: indeks ceny }\left(\mathrm{P}_{\mathrm{t}} / \mathrm{P}_{\mathrm{t}-1}\right) \\
\mathrm{R}=, 02604977 \mathrm{R} \wedge 2=, 00067859 \text { Popraw. } \mathrm{R} 2=----- \\
\mathrm{F}(1,400)=, 27162 \mathrm{p}<, 60254 \text { Błąd std. estymacji: }, 96433\end{array}$} \\
\hline & $b^{*}$ & Bl. std. & $\mathrm{b}$ & B1. std. & $\mathrm{t}(400)$ & $\mathrm{p}$ \\
\hline W. wolny & & & 0,242 & 0,048 & 5,023 & 0,000 \\
\hline $\operatorname{Zmn}\left(\mathrm{X}_{\mathrm{t}-1} / \mathrm{P}_{\mathrm{t}-1)}\right)$ & $-0,026$ & 0,050 & $-0,028$ & 0,054 & $-0,521$ & 0,603 \\
\hline \multicolumn{7}{|c|}{$\begin{array}{l}\text { Wskaźnik jakości zysku EQ2 - zdolność prognostyczna } \\
\text { (najlepsze 40\%) }\end{array}$} \\
\hline \multirow[t]{2}{*}{$\mathrm{N}=401$} & \multicolumn{6}{|c|}{$\begin{array}{l}\text { Podsumowanie regresji zmiennej zależnej: indeks ceny }\left(\mathrm{P}_{\mathrm{t}} / \mathrm{P}_{\mathrm{t}-1}\right) \\
\mathrm{R}=, 12934951 \mathrm{R} \wedge 2=, 01673130 \text { Popraw. } R 2=, 01426696 \\
\mathrm{~F}(1,399)=6,7894 \mathrm{p}<, 00951 \text { Błąd std. estymacji: }, 70057\end{array}$} \\
\hline & $\mathrm{b}^{*}$ & Bł. std. & $\mathrm{b}$ & B1. std. & $\mathrm{t}(399)$ & $\mathrm{p}$ \\
\hline W. wolny & & & 0,1469 & 0,0351 & 4,1889 & 0,0000 \\
\hline $\operatorname{Zmn}\left(\mathrm{X}_{\mathrm{t}-1} / \mathrm{P}_{\mathrm{t}-1)}\right)$ & 0,1293 & 0,0496 & 0,1414 & 0,0543 & 2,6056 & 0,0095 \\
\hline \multicolumn{7}{|c|}{ (najgorsze 40\%) } \\
\hline \multirow[t]{2}{*}{$\mathrm{N}=402$} & \multicolumn{6}{|c|}{$\begin{array}{l}\text { Podsumowanie regresji zmiennej zależnej: indeks ceny }\left(\mathrm{P}_{\mathrm{t}} / \mathrm{P}_{\mathrm{t}-1}\right) \\
\mathrm{R}=, 03437544 \mathrm{R} \wedge 2=, 00118167 \text { Popraw. } \mathrm{R} 2=----- \\
\mathrm{F}(1,400)=, 47323 \mathrm{p}<, 49190 \text { Błąd std. estymacji: ,96316” }\end{array}$} \\
\hline & $\mathrm{b}^{*}$ & Bł. std. & $\mathrm{b}$ & B1. std. & $\mathrm{t}(400)$ & $\mathrm{p}$ \\
\hline W. wolny & & & 0,226 & 0,048 & 4,699 & 0,000 \\
\hline $\operatorname{Zmn}\left(\mathrm{X}_{\mathrm{t}-1} / \mathrm{P}_{\mathrm{t}-1)}\right)$ & $-0,034$ & 0,050 & $-0,037$ & 0,054 & $-0,688$ & 0,492 \\
\hline
\end{tabular}


Tabela $2 \mathrm{~cd}$.

\begin{tabular}{|c|c|c|c|c|c|c|}
\hline & \multicolumn{6}{|c|}{$\begin{array}{c}\text { Wskaźnik jakości zysku EQ3 - wygładzenie zysku } \\
\text { (najlepsze 40\%) }\end{array}$} \\
\hline \multirow[t]{2}{*}{$\mathrm{N}=401$} & \multicolumn{6}{|c|}{$\begin{array}{l}\text { Podsumowanie regresji zmiennej zależnej: indeks ceny }\left(\mathrm{P}_{\mathrm{t}} / \mathrm{P}_{\mathrm{t}-1}\right) \\
\mathrm{R}=, 02936645 \mathrm{R} \wedge 2=, 00086239 \text { Popraw. } \mathrm{R} 2=---- \\
\mathrm{F}(1,399)=, 34439 \mathrm{p}<, 55764 \text { Błąd std. estymacji: ,84526 }\end{array}$} \\
\hline & $\mathrm{b}^{*}$ & Bł. std. & $\mathrm{b}$ & Bł. std. & $\mathrm{t}(399)$ & $\mathrm{p}$ \\
\hline W. wolny & & & 0,174 & 0,043 & 4,089 & 0,000 \\
\hline $\operatorname{Zmn}\left(\mathrm{X}_{\mathrm{t}-1} / \mathrm{P}_{\mathrm{t}-1)}\right)$ & 0,029 & 0,050 & 0,030 & 0,051 & 0,587 & 0,558 \\
\hline \multicolumn{7}{|c|}{ (najgorsze 40\%) } \\
\hline \multirow[t]{2}{*}{$\mathrm{N}=402$} & \multicolumn{6}{|c|}{$\begin{array}{l}\text { Podsumowanie regresji zmiennej zależnej: indeks ceny }\left(\mathrm{P}_{\mathrm{t}} / \mathrm{P}_{\mathrm{t}-1}\right) \\
\mathrm{R}=, 01751344 \mathrm{R} \wedge 2=, 00030672 \text { Popraw. } \mathrm{R} 2=----- \\
\mathrm{F}(1,400)=, 12273 \mathrm{p}<, 72628 \text { Błąd std. estymacji: ,84581” }\end{array}$} \\
\hline & $b^{*}$ & Bł. std. & $\mathrm{b}$ & Bł. std. & $\mathrm{t}(400)$ & $\mathrm{p}$ \\
\hline W. wolny & & & 0,200 & 0,042 & 4,746 & 0,000 \\
\hline $\operatorname{Zmn}\left(\mathrm{X}_{\mathrm{t}-1} / \mathrm{P}_{\mathrm{t}-1)}\right)$ & 0,018 & 0,050 & 0,020 & 0,058 & 0,350 & 0,726 \\
\hline \multicolumn{7}{|c|}{$\begin{array}{c}\text { Wskaźnik jakości zysku EQ4 - stabilność zysku } \\
\text { (najlepsze 40\%) }\end{array}$} \\
\hline \multirow[t]{2}{*}{$\mathrm{N}=401$} & \multicolumn{6}{|c|}{$\begin{array}{l}\text { Podsumowanie regresji zmiennej zależnej: indeks ceny }\left(\mathrm{P}_{\mathrm{t}} / \mathrm{P}_{\mathrm{t}-1}\right) \\
\mathrm{R}=, 27233289 \mathrm{R} \wedge 2=, 07416521 \text { Popraw. } R 2=, 07184482 \\
\mathrm{~F}(1,399)=31,962 \mathrm{p}<, 00000 \text { Błąd std. estymacji: }, 61029\end{array}$} \\
\hline & $b^{*}$ & Bł. std. & $\mathrm{b}$ & Bł. std. & $\mathrm{t}(399)$ & $\mathrm{p}$ \\
\hline W. wolny & & & 0,1823 & 0,0313 & 5,8239 & 0,0000 \\
\hline $\operatorname{Zmn}\left(\mathrm{X}_{\mathrm{t}-1} / \mathrm{P}_{\mathrm{t}-1)}\right)$ & 0,2723 & 0,0482 & 0,2773 & 0,0490 & 5,6535 & 0,0000 \\
\hline \multicolumn{7}{|c|}{ (najgorsze 40\%) } \\
\hline \multirow[t]{2}{*}{$\mathrm{N}=402$} & \multicolumn{6}{|c|}{$\begin{array}{l}\text { „Podsumowanie regresji zmiennej zależnej: indeks ceny }\left(\mathrm{P}_{\mathrm{t}} / \mathrm{P}_{\mathrm{t}-1}\right) \\
\mathrm{R}=, 09204333 \mathrm{R} \wedge 2=, 00847198 \text { Popraw. } \mathrm{R} 2=, 00599316 \\
\mathrm{~F}(1,400)=3,4177 \mathrm{p}<, 06524 \text { Błąd std. estymacji: } 1,0084\end{array}$} \\
\hline & $b^{*}$ & Bł. std. & $\mathrm{b}$ & Bł. std. & $\mathrm{t}(400)$ & $\mathrm{p}$ \\
\hline W. wolny & & & 0,151 & 0,050 & 2,991 & 0,003 \\
\hline $\operatorname{Zmn}\left(\mathrm{X}_{\mathrm{t}-1} / \mathrm{P}_{\mathrm{t}-1)}\right)$ & $-0,092$ & 0,050 & $-0,104$ & 0,056 & $-1,849$ & 0,065 \\
\hline
\end{tabular}

* wielkości statystycznie istotne zostały przedstawione kursywą

Źródło: opracowanie własne na podstawie danych spótek.

poza sektorem handlowym w pozostałych przypadkach przydatność zysku dla prognozowania stopy zwrotu $\mathrm{z}$ akcji jest bardzo niska bądź też wpływ ten jest negatywny. Po uwzględnieniu parametru jakościowego EQ4, „stabilność zysku” w sektorze przemysłowym współczynnik ERC rośnie do 1,458 przy $\mathrm{R}^{2}=0,29$. W przypadku sektora handlowego zastosowanie parametru EQ3 (wygładzenie zysku) zwiększa wartość współczynnika ERC do 0,634 przy $\mathrm{R}^{2}=0,22$. W ramach sektora budowlanego oparcie oceny jakości zysku na wskaźniku EQ2 powoduje wzrost współczynnika ERC 
Tabela 3. Analiza zależności pomiędzy wynikiem finansowym a stopą zwrotu z akcji dla próby obejmującej spółki z sektora przemysłowego i porównawczo dla 40\% przypadków o najwyższym poziomie wskaźnika jakości zysku

\begin{tabular}{|c|c|c|c|c|c|c|}
\hline \multirow[b]{2}{*}{$\mathrm{N}=379$} & \multicolumn{6}{|c|}{$\begin{array}{l}\text { Podsumowanie regresji zmiennej zależnej: indeks ceny }\left(\mathrm{P}_{\mathrm{t}} / \mathrm{P}_{\mathrm{t}-1}\right) \\
\mathrm{R}=, 12223443 \mathrm{R} \wedge 2=, 01494126 \text { Popraw. } R 2=, 01232837 \\
\mathrm{~F}(1,377)=5,7183 \mathrm{p}<, 01728 \text { Bląd std. estymacji: }, 95591\end{array}$} \\
\hline & $b^{*}$ & B1. std. & $\mathrm{b}$ & B1. std. & $\mathrm{t}(377)$ & $\mathrm{p}$ \\
\hline W. wolny & & & 0,212417 & 0,049412 & 4,298910 & 0,000022 \\
\hline $\operatorname{Zmn}\left(\mathrm{X}_{\mathrm{t}-1} / \mathrm{P}_{\mathrm{t}-1)}\right)$ & 0,122234 & 0,051116 & 0,309035 & 0,129233 & 2,391295 & 0,017279 \\
\hline \multicolumn{7}{|c|}{ Wskaźnik jakości zysku EQ1 } \\
\hline \multirow[t]{2}{*}{$\mathrm{N}=189$} & \multicolumn{6}{|c|}{$\begin{array}{l}\text { Podsumowanie regresji zmiennej zależnej: indeks ceny }\left(\mathrm{P}_{\mathrm{t}} / \mathrm{P}_{\mathrm{t}-1}\right) \\
\mathrm{R}=, 04028316 \mathrm{R} \wedge \\
\mathrm{F}(1,187)=, 30394 \mathrm{p}<, 5820162273 \text { Popraw. } \mathrm{R} 2=----- \\
\end{array}$} \\
\hline & $\mathrm{b}^{*}$ & B1. std. & $\mathrm{b}$ & B1. std. & $\mathrm{t}(187)$ & $\mathrm{p}$ \\
\hline W. wolny & & & 0,203 & 0,061 & 3,305 & 0,001 \\
\hline $\operatorname{Zmn}\left(\mathrm{X}_{\mathrm{t}-1} / \mathrm{P}_{\mathrm{t}-1)}\right)$ & $-0,040$ & 0,073 & $-0,092$ & 0,168 & $-0,551$ & 0,582 \\
\hline \multicolumn{7}{|c|}{ Wskaźnik jakości zysku EQ2 } \\
\hline \multirow[t]{2}{*}{$\mathrm{N}=189$} & \multicolumn{6}{|c|}{$\begin{array}{l}\text { Podsumowanie regresji zmiennej zależnej: indeks ceny }\left(\mathrm{P}_{\mathrm{t}} / \mathrm{P}_{\mathrm{t}-1}\right) \\
\mathrm{R}=, 02239220 \mathrm{R} \wedge 2=, 00050141 \text { Popraw. } \mathrm{R} 2=---- \\
\mathrm{F}(1,187)=, 09381 \mathrm{p}<, 75973 \text { Błąd std. estymacji: ,84510 }\end{array}$} \\
\hline & $\mathrm{b}^{*}$ & Bł. std. & $\mathrm{b}$ & B1. std. & $\mathrm{t}(187)$ & $\mathrm{p}$ \\
\hline W. wolny & & & 0,208 & 0,062 & 3,376 & 0,001 \\
\hline $\operatorname{Zmn}\left(\mathrm{X}_{\mathrm{t}-1} / \mathrm{P}_{\mathrm{t}-1)}\right)$ & $-0,022$ & 0,073 & $-0,053$ & 0,173 & $-0,306$ & 0,760 \\
\hline \multicolumn{7}{|c|}{ Wskaźnik jakości zysku EQ3 } \\
\hline \multirow[t]{2}{*}{$\mathrm{N}=189$} & \multicolumn{6}{|c|}{$\begin{array}{l}\text { Podsumowanie regresji zmiennej zależnej: indeks ceny }\left(\mathrm{P}_{\mathrm{t}} / \mathrm{P}_{\mathrm{t}-1}\right) \\
\mathrm{R}=, 20896468 \mathrm{R} \wedge 2=, 04366624 \text { Popraw. } R 2=, 03855215 \\
\mathrm{~F}(1,187)=8,5384 \mathrm{p}<, 00391 \text { Błąd std. estymacji: }, 92359\end{array}$} \\
\hline & $\mathrm{b}^{*}$ & Bł. std. & $\mathrm{b}$ & B1. std. & $\mathrm{t}(187)$ & $\mathrm{p}$ \\
\hline W. wolny & & & 0,174 & 0,068 & 2,573 & 0,011 \\
\hline $\operatorname{Zmn}\left(\mathrm{X}_{\mathrm{t}-1} / \mathrm{P}_{\mathrm{t}-1)}\right)$ & 0,209 & 0,072 & 0,424 & 0,145 & 2,922 & 0,004 \\
\hline \multicolumn{7}{|c|}{ Wskaźnik jakości zysku EQ4 } \\
\hline \multirow[t]{2}{*}{$\mathrm{N}=189$} & \multicolumn{6}{|c|}{$\begin{array}{l}\text { Podsumowanie regresji zmiennej zależnej: indeks ceny }\left(\mathrm{P}_{\mathrm{t}} / \mathrm{P}_{\mathrm{t}-1}\right) \\
\mathrm{R}=, 54575692 \mathrm{R} \wedge 2=, 29785061 \text { Popraw. } R 2=, 29409580 \\
\mathrm{~F}(1,187)=79,325 \mathrm{p}<, 00000 \text { Błąd std. estymacji: }, 60662\end{array}$} \\
\hline & $\mathrm{b}^{*}$ & Bł. std. & $\mathrm{b}$ & B1. std. & $\mathrm{t}(187)$ & $\mathrm{p}$ \\
\hline W. wolny & & & 0,145 & 0,046 & 3,171 & 0,002 \\
\hline $\operatorname{Zmn}\left(\mathrm{X}_{\mathrm{t}-1} / \mathrm{P}_{\mathrm{t}-1)}\right)$ & 0,546 & 0,061 & 1,458 & 0,164 & 8,906 & 0,000 \\
\hline
\end{tabular}

Źródło: opracowanie własne na podstawie danych spółek.

do 0,424 przy $\mathrm{R}^{2}=0,22$. We wszystkich tych przypadkach wskaźnik EPS jako zmienna objaśniająca jest statystycznie istotny.

Wyniki analizy regresji przeprowadzone dla poszczególnych lat potwierdziły także rezultaty innych badań, że przydatność zysku dla procesu prognozowania stopy zwrotu z akcji jest różna w czasie. W roku 2009 współczynnik estymacji ERC dla danych surowych osiągnął poziom 0,28 przy $\mathrm{R}^{2}=0,038$, w roku 2010 wartość ERC wyniosła 0,97 przy $\mathrm{R}^{2}=0,10$, w roku 2011 $\mathrm{ERC}=0,30$ przy $\mathrm{R}^{2}=0,03, \mathrm{w}$ roku 2012 wartość współczynnika spadła do 0,09 
Tabela 4. Analiza zależności pomiędzy wynikiem finansowym a stopą zwrotu z akcji dla próby obejmującej spółki z sektora handlowego i porównawczo dla 40\% przypadków o najwyższym poziomie wskaźnika jakości zysku

\begin{tabular}{|c|c|c|c|c|c|c|}
\hline \multirow[b]{2}{*}{$\mathrm{N}=98$} & \multicolumn{6}{|c|}{$\begin{array}{l}\text { Podsumowanie regresji zmiennej zależnej: indeks ceny }\left(\mathrm{P}_{\mathrm{t}} / \mathrm{P}_{\mathrm{t}-1}\right) \\
\mathrm{R}=, 42453273 \mathrm{R} \wedge 2=, 18022804 \text { Popraw. } \mathrm{R} 2=, 17168875 \\
\mathrm{~F}(1,96)=21,106 \mathrm{p}<, 00001 \text { Błąd std. estymacji: }, 44733\end{array}$} \\
\hline & $\mathrm{b}^{*}$ & Bł. std. & $\mathrm{b}$ & Bł. std. & $\mathrm{t}(96)$ & $\mathrm{p}$ \\
\hline W. wolny & & & 0,142 & 0,045 & 3,135 & 0,002 \\
\hline $\operatorname{Zmn}\left(\mathrm{X}_{\mathrm{t}-1} / \mathrm{P}_{\mathrm{t}-1)}\right)$ & 0,425 & 0,092 & 0,572 & 0,124 & 4,594 & 0,000 \\
\hline \multicolumn{7}{|c|}{ Wskaźnik jakości zysku EQ1 } \\
\hline \multirow[t]{2}{*}{$\mathrm{N}=49$} & \multicolumn{6}{|c|}{$\begin{array}{l}\text { Podsumowanie regresji zmiennej zależnej: indeks ceny }\left(\mathrm{P}_{\mathrm{t}} / \mathrm{P}_{\mathrm{t}-1}\right) \\
\mathrm{R}=, 30753901 \mathrm{R} \wedge 2=, 09458024 \text { Popraw. } \mathrm{R} 2=, 07531599 \\
\mathrm{~F}(1,47)=4,9096 \mathrm{p}<, 03159 \text { Błąd std. estymacji: ,43597 }\end{array}$} \\
\hline & $\mathrm{b}^{*}$ & Bł. std. & $\mathrm{b}$ & Bł. std. & $\mathrm{t}(47)$ & $\mathrm{p}$ \\
\hline W. wolny & & & 0,059 & 0,064 & 0,932 & 0,356 \\
\hline $\operatorname{Zmn}\left(\mathrm{X}_{\mathrm{t}-1} / \mathrm{P}_{\mathrm{t}-1)}\right)$ & 0,308 & 0,139 & 0,722 & 0,326 & 2,216 & 0,032 \\
\hline \multicolumn{7}{|c|}{ Wskaźnik jakości zysku EQ2 } \\
\hline \multirow[t]{2}{*}{$\mathrm{N}=49$} & \multicolumn{6}{|c|}{$\begin{array}{l}\text { Podsumowanie regresji zmiennej zależnej: indeks ceny }\left(\mathrm{P}_{\mathrm{t}} / \mathrm{P}_{\mathrm{t}-1}\right) \\
\mathrm{R}=, 31438076 \mathrm{R} \wedge \\
\mathrm{F}(1,47)=5,1547 \mathrm{p}<, 02781 \text { Błąd std. estymacji: }, 44397\end{array}$} \\
\hline & $\mathrm{b}^{*}$ & Bł. std. & $\mathrm{b}$ & Bł. std. & $\mathrm{t}(47)$ & $\mathrm{p}$ \\
\hline W. wolny & & & 0,080 & 0,065 & 1,220 & 0,229 \\
\hline $\operatorname{Zmn}\left(\mathrm{X}_{\mathrm{t}-1} / \mathrm{P}_{\mathrm{t}-1)}\right)$ & 0,314 & 0,138 & 0,781 & 0,344 & 2,270 & 0,028 \\
\hline \multicolumn{7}{|c|}{ Wskaźnik jakości zysku EQ3 } \\
\hline \multirow[t]{2}{*}{$\mathrm{N}=49$} & \multicolumn{6}{|c|}{$\begin{array}{l}\text { Podsumowanie regresji zmiennej zależnej: indeks ceny }\left(\mathrm{P}_{\mathrm{t}} / \mathrm{P}_{\mathrm{t}-1}\right) \\
\mathrm{R}=, 49198473 \mathrm{R} \wedge 2=, 24204898 \text { Popraw. } \mathrm{R} 2=, 22592236 \\
\mathrm{~F}(1,47)=15,009 \mathrm{p}<, 00033 \text { Błąd std. estymacji: }, 40059\end{array}$} \\
\hline & $\mathrm{b}^{*}$ & Bl. std. & $\mathrm{b}$ & B1. std. & $\mathrm{t}(47)$ & $\mathrm{p}$ \\
\hline W. wolny & & & 0,110 & 0,057 & 1,912 & 0,062 \\
\hline $\operatorname{Zmn}\left(\mathrm{X}_{\mathrm{t}-1} / \mathrm{P}_{\mathrm{t}-1)}\right)$ & 0,492 & 0,127 & 0,634 & 0,164 & 3,874 & 0,000 \\
\hline \multicolumn{7}{|c|}{ Wskaźnik jakości zysku EQ4 } \\
\hline \multirow[t]{2}{*}{$\mathrm{N}=49$} & \multicolumn{6}{|c|}{$\begin{array}{l}\text { Podsumowanie regresji zmiennej zależnej: indeks ceny }\left(\mathrm{P}_{\mathrm{t}} / \mathrm{P}_{\mathrm{t}-1}\right) \\
\mathrm{R}=, 46966365 \mathrm{R} \wedge 2=, 22058394 \text { Popraw. } \mathrm{R} 2=, 20400062 \\
\mathrm{~F}(1,47)=13,302 \mathrm{p}<, 00066 \text { Błąd std. estymacji: } 45810\end{array}$} \\
\hline & $\mathrm{b}^{*}$ & Bł. std. & $\mathrm{b}$ & B1. std. & $\mathrm{t}(47)$ & $\mathrm{p}$ \\
\hline W. wolny & & & 0,251 & 0,068 & 3,705 & 0,001 \\
\hline $\operatorname{Zmn}\left(\mathrm{X}_{\mathrm{t}-1} / \mathrm{P}_{\mathrm{t}-1)}\right)$ & 0,470 & 0,129 & 0,572 & 0,157 & 3,647 & 0,001 \\
\hline
\end{tabular}

Źródło: opracowanie własne na podstawie danych spółek.

przy $\mathrm{R}^{2}=0,028$, w roku 2013 obserwujemy silny wzrost wartości współczynnika ERC do poziomu 1,29 przy bardzo wysokim poziomie współczynnika determinacji $\mathrm{R}^{2}=0,78$. W roku 2014 parametry estymacji spadają. Współczynnik ERC osiągnął wartość ujemną $(-0,13)$ przy $\mathrm{R}^{2}=0,03$ i tendencja ta utrzymuje się także w roku
2015. ERC osiagnał wartość 0,04 przy $\mathrm{R}^{2}=0,003$. Wprowadzenie do procesu estymacji parametru jakościowego wpływa na wzrost użyteczności zysku we wszystkich latach, ale podobnie jak przy danych surowych wpływ ten jest różny w poszczególnych latach. W roku 2009 wprowadzenie do procesu estymacji oceny jakości 
Tabela 5. Analiza zależności pomiędzy wynikiem finansowym a stopą zwrotu z akcji dla próby obejmującej spółki z sektora budowlanego i porównawczo dla 40\% przypadków o najwyższym poziomie wskaźnika jakości zysku

\begin{tabular}{|c|c|c|c|c|c|c|}
\hline \multirow[b]{2}{*}{$\mathrm{N}=136$} & \multicolumn{6}{|c|}{$\begin{array}{l}\text { Podsumowanie regresji zmiennej zależnej: indeks ceny }\left(\mathrm{P}_{\mathrm{t}} / \mathrm{P}_{\mathrm{t}-1}\right) \\
\mathrm{R}=, 04641246 \mathrm{R} \wedge 2=, 00215412 \text { Popraw. } \mathrm{R} 2=---- \\
\mathrm{F}(1,134)=, 28927 \mathrm{p}<, 59158 \text { Błąd std. estymacji: } 1,0209\end{array}$} \\
\hline & $\mathrm{b}^{*}$ & Bł. std. & $\mathrm{b}$ & B1. std. & $\mathrm{t}(134)$ & $\mathrm{p}$ \\
\hline W. wolny & & & 0,180 & 0,088 & 2,056 & 0,042 \\
\hline $\operatorname{Zmn}\left(\mathrm{X}_{\mathrm{t}-1} / \mathrm{P}_{\mathrm{t}-1)}\right)$ & $-0,046$ & 0,086 & $-0,011$ & 0,020 & $-0,538$ & 0,592 \\
\hline \multicolumn{7}{|c|}{ Wskaźnik jakości zysku EQ1 } \\
\hline \multirow[t]{2}{*}{$\mathrm{N}=68$} & \multicolumn{6}{|c|}{$\begin{array}{l}\text { Podsumowanie regresji zmiennej zależnej: indeks ceny }\left(\mathrm{P}_{\mathrm{t}} / \mathrm{P}_{\mathrm{t}-1}\right) \\
\mathrm{R}=, 03953883 \mathrm{R} \wedge 2=, 00156332 \text { Popraw. } \mathrm{R} 2=---- \\
\mathrm{F}(1,66)=, 10334 \mathrm{p}<, 74887 \text { Błąd std. estymacji: ,55521 }\end{array}$} \\
\hline & $\mathrm{b}^{*}$ & Bł. std. & $\mathrm{b}$ & Bł. std. & $\mathrm{t}(66)$ & $\mathrm{p}$ \\
\hline W. wolny & & & 0,050 & 0,068 & 0,742 & 0,461 \\
\hline $\operatorname{Zmn}\left(\mathrm{X}_{\mathrm{t}-1} / \mathrm{P}_{\mathrm{t}-1)}\right)$ & 0,040 & 0,123 & 0,004 & 0,012 & 0,321 & 0,749 \\
\hline \multicolumn{7}{|c|}{ Wskaźnik jakości zysku EQ2 } \\
\hline \multirow[t]{2}{*}{$\mathrm{N}=68$} & \multicolumn{6}{|c|}{$\begin{array}{l}\text { Podsumowanie regresji zmiennej zależnej: indeks ceny }\left(\mathrm{P}_{\mathrm{t}} / \mathrm{P}_{\mathrm{t}-1}\right) \\
\mathrm{R}=, 48006816 \mathrm{R} \wedge 2=, 23046544 \text { Popraw. } \mathrm{R} 2=, 21880582 \\
\mathrm{~F}(1,66)=19,766 \mathrm{p}<, 00003 \text { Błąd std. estymacji: } 47884\end{array}$} \\
\hline & $\mathrm{b}^{*}$ & Bł. std. & $\mathrm{b}$ & Bł. std. & $\mathrm{t}(66)$ & $\mathrm{p}$ \\
\hline W. wolny & & & 0,036 & 0,058 & 0,618 & 0,539 \\
\hline $\operatorname{Zmn}\left(\mathrm{X}_{\mathrm{t}-1} / \mathrm{P}_{\mathrm{t}-1)}\right)$ & 0,480 & 0,108 & 0,424 & 0,095 & 4,446 & 0,000 \\
\hline \multicolumn{7}{|c|}{ Wskaźnik jakości zysku EQ3 } \\
\hline \multirow[t]{2}{*}{$\mathrm{N}=68$} & \multicolumn{6}{|c|}{$\begin{array}{l}\text { Podsumowanie regresji zmiennej zależnej: indeks ceny }\left(\mathrm{P}_{\mathrm{t}} / \mathrm{P}_{\mathrm{t}-1}\right) \\
\mathrm{R}=, 10289268 \mathrm{R} \wedge 2=, 01058690 \text { Popraw. } \mathrm{R} 2=----- \\
\mathrm{F}(1,66)=, 70621 \mathrm{p}<, 40374 \text { Błąd std. estymacji: } 1,2832\end{array}$} \\
\hline & $b^{*}$ & Bł. std. & $\mathrm{b}$ & Bł. std. & $\mathrm{t}(66)$ & $\mathrm{p}$ \\
\hline W. wolny & & & 0,206 & 0,156 & 1,319 & 0,192 \\
\hline $\operatorname{Zmn}\left(\mathrm{X}_{t-1} / \mathrm{P}_{t-1)}\right)$ & $-0,103$ & 0,122 & $-0,023$ & 0,027 & $-0,840$ & 0,404 \\
\hline \multicolumn{7}{|c|}{ Wskaźnik jakości zysku EQ4 } \\
\hline \multirow[t]{2}{*}{$\mathrm{N}=68$} & \multicolumn{6}{|c|}{$\begin{array}{l}\text { Podsumowanie regresji zmiennej zależnej: indeks ceny }\left(\mathrm{P}_{\mathrm{t}} / \mathrm{P}_{\mathrm{t}-1}\right) \\
\mathrm{R}=, 18207641 \mathrm{R} \wedge 2=, 03315182 \text { Popraw. } \mathrm{R} 2=, 01850260 \\
\mathrm{~F}(1,66)=2,2630 \mathrm{p}<, 13726 \text { Błąd std. estymacji: } 1,2895\end{array}$} \\
\hline & $\mathrm{b}^{*}$ & Bł. std. & $\mathrm{b}$ & Bł. std. & $\mathrm{t}(66)$ & $\mathrm{p}$ \\
\hline W. wolny & & & 0,348 & 0,157 & 2,215 & 0,030 \\
\hline $\operatorname{Zmn}\left(\mathrm{X}_{\mathrm{t}-1} / \mathrm{P}_{\mathrm{t}-1)}\right)$ & $-0,182$ & 0,121 & $-0,116$ & 0,077 & $-1,504$ & 0,137 \\
\hline
\end{tabular}

Źródło: opracowanie własne na podstawie danych spółek.

zysku przy wykorzystaniu wskaźnika EQ3 zwiększa współczynnik estymacji ERC do poziomu $\mathrm{ERC}=0,351$ przy $\mathrm{R}^{2}=0,25$. Podobnie w roku 2010 wykorzystanie wskaźnika EQ3 zwiększa wartość współczynnika estymacji ERC do poziomu 1,32 przy $\mathrm{R}^{2}=0,23$. W roku 2011 wprowadzenie parametru jakościowego zysku przy wyko- rzystaniu wskaźnika EQ1 wpływa pozytywnie na wyniki estymacji, zwiększając współczynnik ERC do poziomu 0,65 przy $\mathrm{R}^{2}=0,14$, a w roku 2012 do poziomu 0,12 przy $\mathrm{R}^{2}=0,073$. W roku 2013 można zaobserwować bardzo silny wzrost parametrów estymacji. Podział próby badawczej według parametru EQ4 zwiększa wartość współ- 
Tabela 6. Wpływ jakości zysku na zależność pomiędzy wynikiem finansowym a stopą zwrotu z akcji w latach 2009-2015

\begin{tabular}{|c|c|c|c|c|c|c|c|c|c|}
\hline & & & & & & & & & \\
\hline \multirow[t]{2}{*}{$\mathrm{N}=80$} & \multicolumn{2}{|c|}{$\begin{array}{c}\mathrm{R}^{\wedge} 2=, 05 \\
\text { Pop.R2 }=\mathbf{0 3 8}\end{array}$} & \multirow[b]{2}{*}{$\mathrm{N}=82$} & \multicolumn{2}{|c|}{$\begin{array}{c}\mathrm{R}^{\wedge} 2=, 11 \\
\text { Pop.R2 }=, \mathbf{1 0}\end{array}$} & \multirow[b]{2}{*}{$\mathrm{N}=84$} & \multicolumn{2}{|c|}{$\begin{array}{c}\mathrm{R}^{\wedge} 2=, 04 \\
\text { Pop. } \mathbf{R} \mathbf{2}=\mathbf{, 0 3}\end{array}$} & \multirow[b]{2}{*}{$\mathrm{N}=110$} \\
\hline & $\mathrm{b}$ & $\mathrm{p}$ & & b & $\mathrm{p}$ & & $\mathrm{b}$ & $\mathrm{p}$ & \\
\hline W. wolny & 0,524 & 0,000 & & 0,024 & 0,501 & & $-0,252$ & 0,000 & \\
\hline $\mathrm{Zmn}$ & 0,280 & 0,047 & & 0,971 & 0,002 & & 0,308 & 0,078 & \\
\hline
\end{tabular}

Wskaźnik jakości zysku EQ1 - wyniki estymacji dla 40\% najlepszych

\begin{tabular}{|c|c|c|c|c|c|c|c|c|c|}
\hline \multirow[t]{2}{*}{$\mathrm{N}=40$} & \multicolumn{2}{|c|}{$\begin{array}{c}\mathrm{R}^{\wedge} 2=, 07 \\
\text { Pop. } \mathbf{R} \mathbf{2}=\mathbf{0 5}\end{array}$} & \multirow[b]{2}{*}{$\mathrm{N}=41$} & \multicolumn{2}{|c|}{$\begin{array}{c}\mathrm{R}^{\wedge} 2=, 12 \\
\text { Pop. } \mathbf{R} \mathbf{2}=\mathbf{1 0}\end{array}$} & \multirow[t]{2}{*}{$\mathrm{N}=42$} & \multicolumn{2}{|c|}{$\begin{array}{c}\mathrm{R}^{\wedge} 2=, 16 \\
\text { Pop. R2 }=, 14\end{array}$} & \multirow[t]{2}{*}{$\mathrm{N}=55$} \\
\hline & $\mathrm{b}$ & $\mathrm{p}$ & & $\mathrm{b}$ & $\mathrm{p}$ & & $\mathrm{b}$ & $\mathrm{p}$ & \\
\hline W. wolny & 0,390 & 0,000 & & 0,041 & 0,402 & & $-0,303$ & 0,000 & \\
\hline $\mathrm{Zmn}$ & 1,240 & 0,084 & & 0,974 & 0,026 & & 0,654 & 0,009 & \\
\hline
\end{tabular}

Wskaźnik jakości zysku EQ2 - wyniki estymacji dla 40\% najlepszych

\begin{tabular}{|c|c|c|c|c|c|c|c|c|c|}
\hline \multirow[t]{2}{*}{$\mathrm{N}=40$} & \multicolumn{2}{|c|}{$\begin{array}{c}\mathrm{R}^{\wedge} 2=, 12 \\
\text { Pop. } \mathrm{R} 2=, \mathbf{1 0}\end{array}$} & \multirow[b]{2}{*}{$\mathrm{N}=41$} & \multicolumn{2}{|c|}{$\begin{array}{c}\mathrm{R}^{\wedge} 2=, 05 \\
\text { Pop. } \mathbf{R} \mathbf{2}=\mathbf{0 2}\end{array}$} & \multirow[t]{2}{*}{$\mathrm{N}=42$} & \multicolumn{2}{|c|}{$\begin{array}{c}\mathrm{R}^{\wedge} 2=, 11 \\
\text { Pop. } \mathrm{R} 2=, 08\end{array}$} & \multirow[t]{2}{*}{$\mathrm{N}=55$} \\
\hline & $\mathrm{b}$ & $\mathrm{p}$ & & $\mathrm{b}$ & $\mathrm{p}$ & & $\mathrm{b}$ & $\mathrm{p}$ & \\
\hline W. wolny & 0,420 & 0,000 & & 0,052 & 0,325 & & $-0,308$ & 0,000 & \\
\hline $\mathrm{Zmn}$ & 1,277 & 0,030 & & 0,587 & 0,170 & & 0,552 & 0,035 & \\
\hline
\end{tabular}

Wskaźnik jakości zysku EQ3- wyniki estymacji dla 40\% najlepszych

\begin{tabular}{|c|c|c|c|c|c|c|c|c|c|}
\hline \multirow[t]{2}{*}{$\mathrm{N}=40$} & \multicolumn{2}{|c|}{$\begin{array}{c}\mathrm{R}^{\wedge} 2=, 27 \\
\text { Pop. } \mathbf{R} \mathbf{2}=\mathbf{2 5}\end{array}$} & \multirow[b]{2}{*}{$\mathrm{N}=41$} & \multicolumn{2}{|c|}{$\begin{array}{c}\mathrm{R}^{\wedge} 2=, 25 \\
\text { Pop. } \mathbf{R} \mathbf{2}=\mathbf{2 3}\end{array}$} & \multirow[t]{2}{*}{$\mathrm{N}=42$} & \multicolumn{2}{|c|}{$\begin{array}{l}\mathrm{R}^{\wedge} 2=, 012 \\
\text { Pop. R2 = --- }\end{array}$} & \multirow[t]{2}{*}{$\mathrm{N}=55$} \\
\hline & $\mathrm{b}$ & $\mathrm{p}$ & & $\mathrm{b}$ & $\mathrm{p}$ & & $\mathrm{b}$ & $\mathrm{p}$ & \\
\hline W. wolny & 0,446 & 0,000 & & 0,004 & 0,941 & & $-0,224$ & 0,000 & \\
\hline $\mathrm{Zmn}$ & 0,351 & 0,000 & & 1,324 & 0,001 & & 0,185 & 0,495 & \\
\hline
\end{tabular}

Wskaźnik jakości zysku EQ4 - wyniki estymacji dla 40\% najlepszych

\begin{tabular}{|c|c|c|c|c|c|c|c|c|c|}
\hline \multirow[t]{2}{*}{$\mathrm{N}=40$} & \multicolumn{2}{|c|}{$\begin{array}{l}\mathrm{R}^{\wedge} 2=, 1508 \\
\text { Pop. } \mathbf{R} \mathbf{2}=\mathbf{, 1 3}\end{array}$} & \multirow[b]{2}{*}{$\mathrm{N}=41$} & \multicolumn{2}{|c|}{$\begin{array}{c}\mathrm{R}^{\wedge} 2=, 14 \\
\text { Pop. R2 = ,11 }\end{array}$} & \multirow[t]{2}{*}{$\mathrm{N}=42$} & \multicolumn{2}{|c|}{$\begin{array}{c}\mathrm{R}^{\wedge} 2=, 03 \\
\text { Pop. } \mathrm{R} 2=, 01\end{array}$} & \multirow[t]{2}{*}{$\mathrm{N}=55$} \\
\hline & $\mathrm{b}$ & $\mathrm{p}$ & & $\mathrm{b}$ & $\mathrm{p}$ & & $\mathrm{b}$ & $\mathrm{p}$ & \\
\hline W. wolny & 0,419 & 0,000 & & $-0,005$ & 0,924 & & $-0,165$ & 0,000 & \\
\hline $\mathrm{Zmn}$ & 0,512 & 0,013 & & 1,280 & 0,018 & & 0,251 & 0,274 & \\
\hline
\end{tabular}

Źródło: opracowanie własne na podstawie danych spółek.

czynnika ERC do poziomu 1,538 a współczynnika determinacji do poziomu 0,96 . W roku 2014 po uwzględnieniu parametru jakości zysku, przydatność tej kategorii ekonomicznej dla prognozowania stopy zwrotu z akcji jest bardzo niska (chociaż wyższa niż w przypadku danych surowych), a wpływ ten jest negatywny. Z kolei w roku 2015 po wprowadzeniu do procesu estymacji oceny jakości zysku z wykorzystaniem parametru EQ4 wyniki estymacji ulegają wyraźnej poprawie. Współczynnik ERC wzrasta do poziomu 1,597 przy $\mathrm{R}^{2}=0,458$.

\section{Podsumowanie}

Rezultaty przeprowadzonego badania pozwalają stwierdzić, iż wynik finansowy (poziom EPS) w warunkach polskiego rynku kapitałowego ma niewielką war- 


\begin{tabular}{|c|c|c|c|c|c|c|c|c|c|c|}
\hline \multirow{2}{*}{\multicolumn{2}{|c|}{$\begin{array}{c}2012 \\
\mathrm{R}^{\wedge} 2=, 04 \\
\text { Pop. R2 }=, 02\end{array}$}} & \multirow[b]{3}{*}{$N=119$} & \multicolumn{2}{|c|}{2013} & & \multicolumn{2}{|c|}{2014} & & \multicolumn{2}{|c|}{2015} \\
\hline & & & \multicolumn{2}{|c|}{$\begin{array}{c}\mathrm{R}^{\wedge} 2=, 80 \\
\text { Pop. } \mathrm{R} 2=, 79\end{array}$} & \multirow[b]{2}{*}{$\mathrm{N}=119$} & \multicolumn{2}{|c|}{$\begin{array}{c}\mathrm{R}^{\wedge} 2=, 042 \\
\text { Pop. } \mathbf{R} \mathbf{2}=\mathbf{0 3}\end{array}$} & \multirow[b]{2}{*}{$\mathrm{N}=119$} & \multicolumn{2}{|c|}{$\begin{array}{l}\mathrm{R}^{\wedge} 2=, 003 \\
\text { Pop. } \mathrm{R} 2=---\end{array}$} \\
\hline $\mathrm{b}$ & $\mathrm{p}$ & & $\mathrm{b}$ & $\mathrm{p}$ & & $\mathrm{b}$ & $\mathrm{p}$ & & $\mathrm{b}$ & $\mathrm{p}$ \\
\hline$-0,045$ & 0,242 & & 0,058 & 0,831 & & 0,268 & 0,000 & & 0,111 & 0,051 \\
\hline 0,097 & 0,043 & & 1,295 & 0,000 & & $-0,137$ & 0,014 & & 0,042 & 0,523 \\
\hline \multicolumn{2}{|c|}{$\begin{array}{c}\mathrm{R}^{\wedge} \text { '2 }=, 09 \\
\text { Pop. } \mathbf{R} \mathbf{2}=\mathbf{0 7}\end{array}$} & \multirow[t]{2}{*}{$\mathrm{N}=59$} & \multicolumn{2}{|c|}{$\begin{array}{l}\mathrm{R}^{\wedge} 2=, 00 \\
\text { Pop. R2 }=--\end{array}$} & \multirow[t]{2}{*}{$\mathrm{N}=71$} & \multicolumn{2}{|c|}{$\begin{array}{c}\mathrm{R}^{\wedge} 2=, 01 \\
\text { Pop. } \mathrm{R} 2=, 00\end{array}$} & \multirow[t]{2}{*}{$\mathrm{N}=84$} & \multicolumn{2}{|c|}{$\begin{array}{c}\mathrm{R}^{\wedge} 2=, 00 \\
\text { Pop. } \mathrm{R} 2=-\end{array}$} \\
\hline$b$ & $\mathrm{p}$ & & $\mathrm{b}$ & $\mathrm{p}$ & & $b$ & $\mathrm{p}$ & & $\mathrm{b}$ & $\mathrm{p}$ \\
\hline 0,008 & 0,876 & & 0,474 & 0,009 & & 0,193 & 0,023 & & 0,026 & 0,472 \\
\hline 0,128 & 0,025 & & 0,006 & 0,953 & & $-0,052$ & 0,321 & & $-0,013$ & 0,758 \\
\hline \multicolumn{2}{|c|}{$\begin{array}{c}\mathrm{R}^{\wedge} 2=, 03 \\
\text { Pop. } \mathrm{R} 2=, 01\end{array}$} & \multirow{2}{*}{$\mathrm{N}=59$} & \multicolumn{2}{|c|}{$\begin{array}{c}\mathrm{R}^{\wedge} 2=, 00 \\
\text { Pop. R2 }=---\end{array}$} & \multirow{2}{*}{$\mathrm{N}=59$} & \multicolumn{2}{|c|}{$\begin{array}{c}\mathrm{R}^{\wedge} 2=, 06 \\
\text { Pop. } \mathrm{R} 2=, 04\end{array}$} & \multirow{2}{*}{$\mathrm{N}=84$} & \multicolumn{2}{|c|}{$\begin{array}{l}\mathrm{R}^{\wedge} 2=, 01 \\
\text { Pop. } \mathrm{R} 2=--\end{array}$} \\
\hline $\mathrm{b}$ & $\mathrm{p}$ & & $\mathrm{b}$ & $\mathrm{p}$ & & $\mathrm{b}$ & $\mathrm{p}$ & & $\mathrm{b}$ & $\mathrm{p}$ \\
\hline$-0,022$ & 0,682 & & 0,534 & 0,003 & & 0,286 & 0,002 & & 0,049 & 0,185 \\
\hline 0,086 & 0,246 & & $-0,003$ & 0,972 & & $-0,109$ & 0,048 & & $-0,031$ & 0,473 \\
\hline \multicolumn{2}{|c|}{$\begin{array}{c}\mathrm{R}^{\wedge} 2=, 01 \\
\text { Pop. } \mathrm{R} 2=---\end{array}$} & \multirow[t]{2}{*}{$\mathrm{N}=59$} & \multicolumn{2}{|c|}{$\begin{array}{c}\mathrm{R}^{\wedge} 2=, 91 \\
\text { Pop. R2 =,91 }\end{array}$} & \multirow[t]{2}{*}{$\mathrm{N}=59$} & \multicolumn{2}{|c|}{$\begin{array}{c}\mathrm{R}^{\wedge} 2=, 03 \\
\text { Pop. } \mathrm{R} 2=, 01\end{array}$} & \multirow[t]{2}{*}{$\mathrm{N}=84$} & \multicolumn{2}{|c|}{$\begin{array}{c}\mathrm{R}^{\wedge} 2=, 00 \\
\text { Pop. } \mathrm{R} 2=--\end{array}$} \\
\hline $\mathrm{b}$ & $\mathrm{p}$ & & $\mathrm{b}$ & $\mathrm{p}$ & & $\mathrm{b}$ & $\mathrm{p}$ & & $\mathrm{b}$ & $\mathrm{p}$ \\
\hline$-0,100$ & 0,072 & & $-0,028$ & 0,938 & & 0,149 & 0,023 & & 0,201 & 0,070 \\
\hline 0,109 & 0,516 & & 1,454 & 0,000 & & $-0,057$ & 0,161 & & 0,032 & 0,724 \\
\hline \multicolumn{2}{|c|}{$\begin{array}{c}\mathrm{R}^{\wedge} 2=, 01 \\
\text { Pop. R2 = --- }\end{array}$} & $\mathrm{N}=59$ & $\begin{array}{r}\mathrm{R}^{\wedge} 2 \\
\text { Pop. R }\end{array}$ & $\begin{array}{l}=, 96 \\
=, 96\end{array}$ & $\mathrm{~N}=59$ & $\begin{array}{r}\mathrm{R}^{\wedge} 2 \\
\text { Pop. R }\end{array}$ & $\begin{array}{l}=, 05 \\
=, 04\end{array}$ & $\mathrm{~N}=84$ & $\begin{array}{r}\mathrm{R}^{\wedge 2} \\
\text { Pop. } \mathrm{F}\end{array}$ & $\begin{array}{l}=, 46 \\
=, 46\end{array}$ \\
\hline b & $\mathrm{p}$ & & $\mathrm{b}$ & $\mathrm{p}$ & & $\mathrm{b}$ & $\mathrm{p}$ & & $\mathrm{b}$ & $\mathrm{p}$ \\
\hline 0,093 & 0,088 & & 0,021 & 0,930 & & 0,240 & 0,048 & & 0,052 & 0,398 \\
\hline$-0,194$ & 0,589 & & 1,538 & 0,000 & & $-0,143$ & 0,054 & & 1,597 & 0,000 \\
\hline
\end{tabular}

tość wyjaśniającą przyszłą zmianę cen akcji, dodatkowo zdolność ta jest zmienna w czasie i zależy od przynależności sektorowej spółki. Wprowadzenie do oceny parametru ,jakości zysku” wywiera pozytywny wpływ na użyteczność zysku jako zmiennej objaśniającej przyszła zmianę stopy zwrotu z akcji - przy czym relacja ta jest również zmienna w czasie i zależy od przynależności sektorowej badanej spółki. Najwyższą efektywność determinującą przydatność informacji w zakresie wyniku finansowego dla procesu prognozowania stopy zwrotu prezentuje wskaźnik EQ4, przy czym efektywność ta także różni się w zależności od branży i roku badania.

Pomimo znalezienia empirycznych dowodów potwierdzających wpływ jakości zysku na użyteczność informacji sprawoz- 
dawczych dla procesu prognozowania stopy zwrotu z akcji to zaobserwowana zmienność wyników w czasie i branżach powoduje, że trudno wskazać na możliwość praktycznego wykorzystania rezultatów badania. Należy jednak podkreślić, iż zamierzeniem autora było raczej wykazanie znaczenia jakości zysku jako nowej kategorii analitycznej, a nie tworzenie nowego modelu prognostycznego. $\mathrm{Z}$ tego względu badanie relacji zysk-stopa zwrotu z akcji została oparta na najprostszym modelu. Niemniej jednak obserwacje dokonane w ramach niniejszego badania stanowią kolejny, szczególnie w warunkach polskich, wkład w dyskusję na temat jakości zysku i jego znaczenia dla efektywności na polskim rynku kapitałowym, a obiecujace wyniki estymacji powinny stanowić przesłankę do dalszych badań w tym zakresie.

\section{Przypis}

1 Badanie pilotażowe zawierające założenia i wstępne wyniki badania zostało opublikowane w: Cieślik (2016).

\section{Bibliografia}

Alaa', A.A. i Al-Debi'e, M.M. (2015). The Effect of Earnings Quality on the Returns-Earnings Relationship: Evidence from Jordan. Accounting and Finance Research, 4, 165-175.

Ball, R. i Brown, P. (1968). An empirical evaluation of accounting income numbers. Journal of Accounting Research, 6(2), 159-177.

Barth, M., Beaver, W. i Landsman, W. (1998). Relative valuation roles of equity book value and net income as a function of financial health. Journal of Accounting and Economics, 25, 1-34.

Beidleman, C.R. (1973). Income smoothing: The role of management. The Accounting Review, 48(4), 653-667.

Bernard, V. (1995). The Feltham-Ohlson Framework: Implications for Empiricists. Contemporary Accounting Research, 733-747.

Bowen, R.M., Rajgopal, S. i Vankatachalam, M (2003). Accounting Discretion, Corporate Governance and Firm Performance. Contemporary Accounting Research, 25(2), 351-405.

Chan, K., Chan, L.K.C., Jegadeesh, N. i Lakonishok J. (2006). Earnings quality and stock returns. Journal of Business, 79(3), 1041-1082.

Cieślik, R. (2016). The effect of earnings persistence, predictability, smoothness and stability on the returns-earnings relationship: evidence from
Warsaw Stock Exchange. Zarzadzanie. Teoria i praktyka, 1, 17-24.

Cho, M. (2005). The usefulness of earnings, the magnitude of price change, and the return-earnings covariance: beyond the ERC and $\mathrm{R}^{2}$. Working Paper, University of Maryland.

Collins, D., Maydew, E. i Weiss, I. (1997). Changes in the value-relevance of earnings and book values over the past forty years. Journal of Accounting and Economics, 24, 39-67.

DeAngelo, H., DeAngelo, L. i Skinner, D. (1994). Accounting choice in troubled companies. Journal of Accounting and Economics, 17(1-2), 113-143.

Dichev, I.D., Graham, J.R., Harvey, C.R. i Rajgopal, S. (2013). Earnings quality: Evidence from the field. Journal of Accounting and Economics, 56(2-3), 1-33, http://dx.doi.org/10.1016/j.jacceco.2013.05.004

Dechow, P. i Dichev, I. (2002). The quality of accruals and earnings: The role of accrual estimation errors. The Accounting Review, 77(Supplement), 35-59.

Dechow, P., Sloan, R. i Sweeney, A. (1995). Detecting earnings management. The Accounting Review, 70, 193-225.

Dechow, P. i Schrand, C. (2004). Earnings Quality. The Research Foundation of CFA Institute.

Francis, J., LaFond, R., Olsson, P.M. i Schipper, K. (2004). Costs of Equity and Earnings Attributes. The Accounting Review, 79(4), 967-1010.

Gajdka, J. i Pietraszewski, P. (2015). Wzrost zysków spółki a stopy zwrotu z akcji. Zeszyty Naukowe Uniwersytetu Szczecińskiego, nr 855 Finanse, Rynki Finansowe, Ubezpieczenia $n r$ 74, t. 2, 93-102.

Hayn, C. (1995). The information content of losses. Journal of Accounting and Economics, 20, 125-153.

Kormendi, R. i Lipe, R. (1987). Earnings innovations, earnings, persistence, and stock returns. Journal of Business, 60(3), 323-345.

Kothari, S.P., Leone, A. i Wasley, C. (2005). Performance matched discretionary accrual measures. Journal of Accounting and Economics, 39, 163-197.

Kothari, S.P. i Zimmerman, J.L. (1995). Price and return models. Journal of Accounting and Economics, 20, 155-192.

Leuz, C., Nanda, D. i Wysocki P. (2003). Earnings management and investor protection: An international comparison. Journal of Financial Economics, 69, 505-527.

Lev, B. i Zarowin, P. (1 999). The boundaries of financial reporting and how to extend them. Journal of Accounting Research, 37, 353-385.

Lev, B. i Thiagarajan, R. (1993). Fundamental information analysis. Journal of Accounting Research, 31, 190-215. 
Lev, B. (1989). On the Usefulness of Earnings and Earnings Research: Lessons and Directions from Two Decades of Empirical Research. Journal of Accounting Research, 27(Supplement), 153-92.

Majewski, S. i Doszyń, M. (2013). Efekty wpływu czynników behawioralnych na stopy zwrotu z akcji spółek sektora budowlanego notowanych na GPW w Warszawie. Prace Naukowe Uniwersytetu Ekonomicznego we Wroctawiu, nr 323 Inwestycje finansowe i ubezpieczenia - tendencje światowe a rynek polski, 170-179.

Melumad, N.D. i Nissim, D. (2009). Line-item analysis of earnings quality. Foundations and Trends in Accounting, 3(2-3), 87-221.

McVay, S. (2006). Earnings management using classification shifting: An examination of core earnings and special items. The Accounting Review, 81(3), 501-531.

Ohlson, J. (1991). The theory of value and earnings and an introduction to the Ball-Brown analysis. Contemporary Accounting Research, 7, 1-19.
Penman, S. i Zhang, X. (2002). Accounting conservatism, the quality of earnings, and stock returns. The Accounting Review, 77, 237-264.

Perotti, P. i Wagenhofer, A. (2014). Earnings Quality Measures and Excess Returns. Journal of Business Finance \& Accounting, 41(5-6), 545-571.

Sloan, R. (1996). Do Stock Prices Fully Reflect Information in Accruals and Cash Flows About Future Earnings? The Accounting Review, 71(3), 289-315.

Watts, R. i Zimmerman, J. (1986). Positive Accounting Theory. Englewood Cliffs, NJ: Prentice Hall.

Watts, R.L. (2003a). Conservatism in accounting Part I: Explanations and implications. Accounting Horizons, 17, 207-221.

Watts, R.L. (2003b). Conservatism in accounting Part II: Evidence and research opportunities. Accounting Horizons, 17, 287-301.

Żurawik, B. (2012). Irracjonalność zachowań inwestorów giełdowych Zarządzanie i Finanse, 10(2/2), 203-218. 